Article

\title{
Supercritical Transesterification of Waste Vegetable Oil: Characteristic Comparison of Ethanol and Methanol as Solvents
}

\author{
Sujeeta Karki ${ }^{1}$, Nawaraj Sanjel ${ }^{2}$, Jeeban Poudel ${ }^{3}$, Ja Hyung Choi ${ }^{1}$ and Sea Cheon Oh ${ }^{1, *}$ \\ 1 Department of Environmental Engineering, Kongju National University, 1223-24 Cheonan-Daero, Seobuk, \\ Chungnam 31080, Korea; sujeetakarki@gmail.com (S.K.); jah9206@naver.com (J.H.C.) \\ 2 Energize Nepal Programme, Kathmandu University, Dhulikhel 45200, Nepal; sanjelnawaraj@gmail.com \\ 3 Waste \& Biomass Energy Technology Center, Kongju National University, 1223-24 Cheonan-Daero, Seobuk, \\ Chungnam 31080, Korea; jeeban1985@gmail.com \\ * Correspondence: ohsec@kongju.ac.kr; Tel.: +82-415-219-423
}

Academic Editor: Magnus Rydén

Received: 15 May 2017; Accepted: 12 June 2017; Published: 17 June 2017

Featured Application: Biodiesel production using supercritical transesterification.

\begin{abstract}
Transesterification of waste vegetable oil is one of the promising partial substitutes for fossil fuels. The degradation characteristics of waste vegetable oil using supercritical alcohols (ethanol and methanol) have been studied in this research. The elementary target was to conduct comparative analysis of the effect of supercritical methanol and supercritical ethanol as solvents on the transesterification along with the analysis of product obtained in terms of carbon number. The experiments were carried out at transesterification temperatures of 250,270 and $290{ }^{\circ} \mathrm{C}$, retention time of 0 to $60 \mathrm{~min}$ at an interval of $15 \mathrm{~min}$ and oil to alcohol molar ratios of 1:6, 1:12 and 1:18 for both alcohols. The conversion increased with increase in transesterification temperature and retention time. At $290{ }^{\circ} \mathrm{C}$, almost $99 \%$ conversion was achieved for 60-min holding time for both alcohols. Increase in conversion of waste vegetable oil was observed as the molar ratio increased. Supercritical transesterification resulted into ester yield higher than $95 \%$ with non-ester composition and glycerol collectively less than $5 \%$.
\end{abstract}

Keywords: supercritical transesterification; waste vegetable oil; biodiesel; supercritical methanol; supercritical ethanol

\section{Introduction}

Diminishing fuel resources along with the urgency to reduce greenhouse gas emissions have been a dominant aspiration for the development of alternative fossil fuels. Fossil fuels, such as petroleum, coal and natural gas are consumed continually to meet the energy requirement of the human race and are correlated with the adverse environmental impacts including global warming [1,2]. Fossil fuels, formed over series of geological activities, are exhausted at a rate more than million times faster than they were formed leaving us in a perilous position specifically for petroleum products [3]. Emphasizing on biofuels, biodiesel can be benefited as an alternative fuel source. Its production from renewable resources such as waste vegetable oil not only makes it biodegradable and non-toxic but also aids in the reduction of $\mathrm{CO}_{2}$ emission [4,5]. The mounting demands and the rapid depletion of reserves is the main reason for soaring in price of petroleum and its products both in national and international level [3]. In addition, in developing countries, the price invested in petrol, its products and diesel dominates overall expenditures forming a major part of those countries' import invoice [3]. 
Biofuel or biodiesel made from natural oils and fats can therefore become a promising substitute for petrol or diesel fuels. Some of the governing factors of biofuel over fossil fuel encompass providing a market for surplus production of vegetable oil, lessen the reliance on imported petroleum, no input towards global warming due to its closed carbon cycle and the depreciated amount of exhaust emission of carbon monoxide, unburned hydrocarbon and particulate emission [6]. Despite the fact that various research have been conducted in the production of biodiesel using diverse feed stock including soya bean oil [7], corn oil [8] olive oil [9], cotton seed oil [10], rapeseed oil [11], line seed oil [4], etc., only few focus on the use of waste vegetable oil (WVO) [12]. The burgeoning use of edible food crops and cash crops over the last couple of years has influenced economic and environmental implications [13]. Commercially, the use of upscale processed vegetable oils as a feedstock is not economically practical, as roughly $70 \%$ of the cost is accounted for by the raw materials $[14,15]$. Tremendous volumes of waste cooking oils are produced globally, especially in developed countries [16]. Mismanagement of such oil can be a threat due to their disposal and contamination issues related to water and land resources. Even if some of the WVO is used for production of soap [4], a dominant part of it is still discharged into the environment. Waste oil comprises the promising element to grow into a new source of high-oleic oil and its full potentiality must be explored to reuse its waste material [17].

One of the popular processes for generating biodiesel from fats or WVO is transesterification of triglyceride by alcohol to produce its esters. The objective of transesterification process is to improve some properties of biofuel such as viscosity, flash point, cetane number, etc. The transesterification or biodiesel production under supercritical conditions (supercritical transesterification) is a catalyst-free chemical reaction between triglycerides, the major component in vegetable oils and/or animal fats, and low molecular weight alcohols, such as methanol and ethanol, at a temperature and pressure over the critical point of the mixture [18]. Meher et al. [19] published an excellent review of biodiesel production by transesterification that examines several successful transesterifications using several low molecular weight alcohols, homogenous acid and base catalysts. Basic homogeneous catalysts have surpassed the acid catalysts because of the rapid reaction time. However, for oils with high concentration of free fatty acids (acid value higher than $2 \mathrm{mg} \mathrm{KOH} / \mathrm{g}$ ), a pre-treatment step is recommended [20]. Heterogeneous catalytic transesterification is an assuring technology for the production of biodiesel as the catalyst can be recycled. In addition, there is less or no wastewater generated during the process, and the separation of biodiesel from glycerol is simple [21]. In addition, Martino et al. [22] advocates the reaction condition to be flexible compared to the supercritical process. Homogeneous and heterogeneous catalytic reactions possess several impediments including sensitivity to high water and FFA content, complicated separation and purification of biodiesel, enormous amount of reaction time and exorbitant cost of catalysts making the process uneconomical. During transesterification, long chains of triglycerides transform to monoesters and glycerol $[4,23,24]$. Free fatty acids in the waste cooking oil are transesterified simultaneously in the supercritical method. Since waste cooking oil incorporates water and free fatty acids, supercritical transesterification reduces the pre-treatment and operating costs. Vehicles dissipate a major portion of the world's energy production. Because of the resemblance between biodiesel and paraffinic oil, this alternative fuel shows a promising future to fulfill the demands of the diesel engine. Moreover, no engine amendment is required to substitute biodiesel for diesel in order to maintain the engine performance [25]. Moreover, biodiesel is superior to diesel fuel in terms of a low sulfur and aromatic content, higher flash point and complete biodegradability [26]. A study carried out by Demirbas [27] analyzes the properties of waste cooking oil, biodiesel from waste vegetable oil (WVO) and commercial fuel reflecting the resemblance between biodiesel and diesel fuels. The study states that the transesterification process of WVO reduced the molecular weight to one-third, viscosity by one-seventh, flash point slightly and increases the volatility marginally.

A few studies have focused on waste vegetable oil $[20,28,29]$ in spite of their immense potential to equivalent the problems associated with fossil fuels. Besides, Warabi et al. [23] studied the reactivity of triglycerides and fatty acids of rapeseed oil in supercritical alcohols. This work therefore focuses 
not only on the biodiesel conversion and qualitative analysis of the product acquired by varying the transesterification temperature, reaction retention time and molar ratio for transesterification reaction of waste vegetable oil in supercritical ethanol (SCE) and supercritical methanol (SCM) but also aims the comparative analysis of the liquid products obtained from transesterification. Furthermore, this study attempts one step further by adding important parameters such as effect of varying molar ratios and detail study of the product based on carbon number. As a detailed product analysis in terms of carbon number has not been done yet using WVO as the raw material and ethanol and methanol as the solvent, a comparison of the effect of two different alcohols in the product has also been carried out.

\section{Raw Material, Experimental Device and Procedure}

The schematic diagram of batch-type reactor manufactured by Parr Instrument Co. (Moline, IL, USA) with volume of $25 \mathrm{~mL}$ is demonstrated in Figure 1. Heating jacket with temperature controller (Hanwoul Engineering, Gunpo, Korea) was used to maintain the desired transesterification temperature. The admissible pressure is $55 \mathrm{MPa}$. Methanol ( $99.5 \%$ purity) and ethanol ( $99.5 \%$ purity) were used as solvents manufactured by Ducksan Chemical Co. (Ansan, Korea) and OCI company Ltd. (Seoul, Korea), respectively. The frying temperature and length of use of the oil along with the material used for frying was responsible for the composition of the waste oil. After repetitive use of the soybean oil for a minimal of $4 \mathrm{~h}$ per day for four consecutive days, the content of free fatty acid (FFA) present in oil sample increased. The fatty acid (FA) and FFA composition of WVO was established by titration against $0.1 \mathrm{M} \mathrm{KOH}$ solution using phenolphthalein as the indicator.

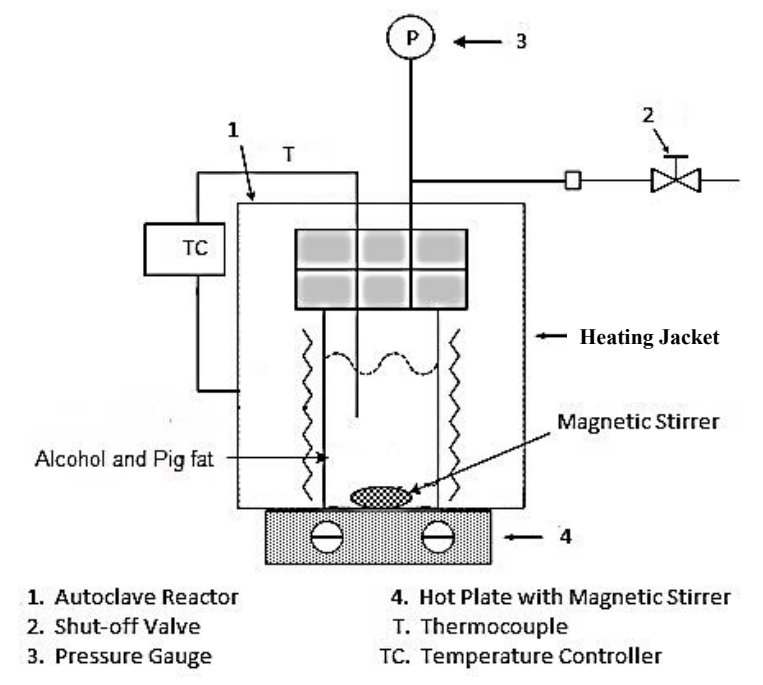

Figure 1. Schematic diagram of the experimental apparatus.

Table 1 illustrates the FA and FFA contents of WVO and virgin oil indicating the elevation in FFA content in WVO from $0.28 \%$ to $3.15 \%$ during cooking. Further, it can be observed that the FA content of 18:2 is notably above than virgin oil, though the FA content of 18:3 is lower for WVO, as a result of the oxidation of the oil during cooking WVO [24]. The experiments were carried out by varying the transesterification temperature $\left(250,270\right.$ and $\left.290^{\circ} \mathrm{C}\right), \mathrm{WVO}$ to alcohol molar ratios (1:6, 1:12 and 1:18), alcohols (SCM and SCE), and reaction retention time (0, 15, 30, 45 and $60 \mathrm{~min})$. At room temperature, the WVO with alcohol at definite molar ratio was loaded into the autoclave reactor. The time required to reach the set point is dependent on heating rates. The average heating rate was $6.2^{\circ} \mathrm{C} / \mathrm{min}$. The reaction pressure was controlled by varying the volume of alcohol and WVO fed into the reactor. The total amount of WVO and alcohol fed into the reactor was determined to ensure that supercritical pressure was reached. The critical temperatures and pressures of ethanol and methanol are $T_{\mathrm{C}}=243.0,239.4{ }^{\circ} \mathrm{C}$ and $P_{\mathrm{C}}=6.4,8.1 \mathrm{MPa}$, respectively. The pressure ranged 7.9-12.8 and 
9.2-14.7 MPa for SCM and SCE, respectively, making them fall in proper supercritical zone. To mix the WVO and alcohol solution homogeneously, a magnetic stirrer was used for rigorous stirring at a rate of $500 \mathrm{rpm}$ during the reaction. The stirring speed used in this study was obtained from a study by Nawaraj et al. [30]. Maintaining a constant heating rate was difficult. Accordingly, set point of the temperature controller was set to a higher temperature than the needed temperature for this experiment. On reaching the desired condition, the heating of the vessel was stopped promptly and the vessel was cooled in an ice bath to halt the reaction instantaneously.

Gas Chromatography Mass Spectrometry (GC-MS) (Agilent GC-6890 with MSD-5975 detector, Santa Clara, CA, USA) was used for the characteristic analysis of liquid products on differing transesterification temperature, retention time, and WVO to alcohol ratios. DB-WAX column (30 $\mathrm{m} \times 250 \mu \mathrm{m}, 0.25 \mu \mathrm{m}$ thickness) was used for all samples. The area percentage method was used to measure the amount of alkyl esters in the product.

Table 1. FA (fatty acid) and FFA (free fatty acid) contents of virgin oil and WVO (waste vegetable oil).

\begin{tabular}{|c|c|c|c|c|c|c|c|}
\hline \multirow{2}{*}{ Sample } & \multicolumn{6}{|c|}{ FA } & \multirow{2}{*}{ FFA } \\
\hline & $13: 2$ & $16: 1$ & 18:1 & $18: 2$ & $18: 3$ & Others & \\
\hline Virgin Oil & 6.49 & 9.86 & 2.41 & 13.58 & 58.48 & 9.19 & 0.28 \\
\hline WVO & 3.38 & 9.89 & 2.41 & 36.70 & 43.21 & 4.42 & 3.15 \\
\hline
\end{tabular}

Note: FA are in area $\%$ and FFA is in wt. $\%$.

\section{Results and Discussion}

The conversion to alkyl esters obtained from the transesterification of WVO in SCM and SCE is shown in Figure 2. There was an increase in conversion with respect to retention time and temperature. The highest conversion obtained was approximately $99 \%$ at $290{ }^{\circ} \mathrm{C}$, and 60 min retention time. Temperature plays a critical part in supercritical alcohol transesterification reaction for biodiesel production. Liquid alcohol is a polar solvent and has hydrogen bonding between $\mathrm{OH}$ oxygen and $\mathrm{OH}$ hydrogen developing alcohol clusters. As the degree of hydrogen bonding reduces with increasing temperature, the polarity of alcohol would decline in supercritical state. This means that supercritical alcohol has a hydrophobic nature with the lower dielectric constant. As a result, non-polar triglycerides can be well solvated with supercritical alcohol to form a single phase [31]. The conversion obtained for lower holding time is lower for SCE for all transesterification temperatures. However, the conversion for SCE abruptly increases for higher holding time resulting into comparatively higher conversion than SCM. Increasing both reaction retention time and temperature had favorable influence on the conversion. Study by Hoffman and Conradi exhibit that, at the supercritical region, the degree of hydrogen bonding of ethanol is somewhat weaker than in methanol [32]. As the temperature accelerates, the degree of hydrogen bonding lowers, demonstrating the possibility that ethanol can work as a better solvent at supercritical conditions. In consonance with the results acquired in this work, the work by Madras at al. [33] also features conversion in supercritical ethanol is higher compared to supercritical methanol during transesterification of sunflower oil. As a result, the solubility parameter of ethanol is closer to the solubility parameter of the oil. According to the work by Madras, the activation energies, computed from the slope of the regressed lines of the Arrhenius plot are 3 and $2 \mathrm{~kJ} / \mathrm{mol}$ for transesterification of sunflower oil using SCM and SCE, respectively, reflecting the higher effectiveness of SCE over SCM. Although the cited work also features the yield obtained using SCM is higher than that achieved using SCE, the difference is quite negligible [34]. 


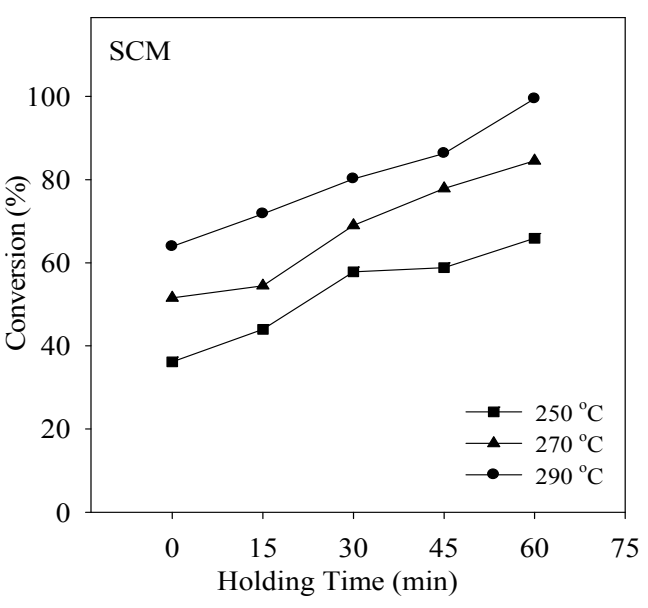

(a)

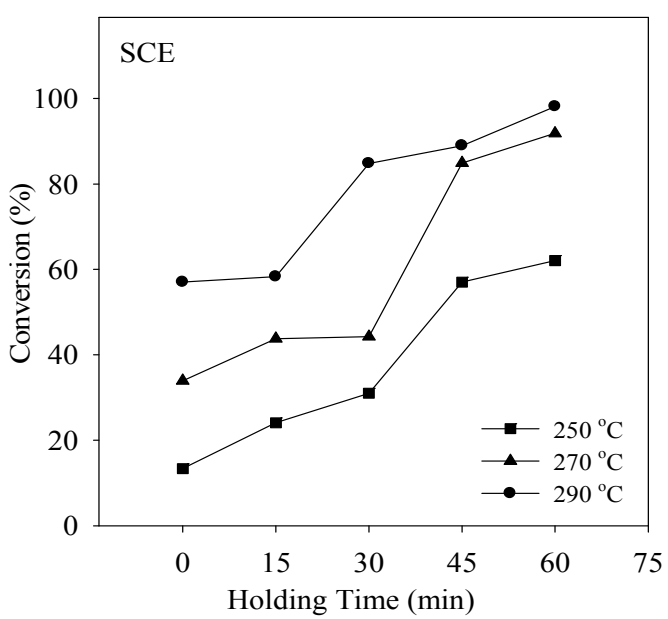

(b)

Figure 2. (a) SCE (supercritical ethanol); (b) SCM (supercritical methanol) based conversion for 1:6 molar ratios of oil to alcohol at different retention time.

Ethanol used as a solvent in biodiesel synthesis is comparatively less toxic than methanol. In Figure 3, it can be inferred that the conversion increases with increase in retention time as well as with higher molar ratio. For all molar ratios, the maximum conversion obtained for both SCM and SCE is approximately $99 \%$ for all molar ratios. In supercritical alcohol reaction, extreme amount of alcohol is used to shift the equilibrium to generate more biodiesel [35]. Although excessive amounts of alcohol can boost the reaction rate, high concentration of alcohol in the reaction mixture can suppress transesterification reaction. Moreover, the purification process of biodiesel turns into energy intensive process because of the amount of alcohol in the product mixture [36]. Hence, the molar ratio should be kept at optimum in supercritical alcohol transesterification reaction.

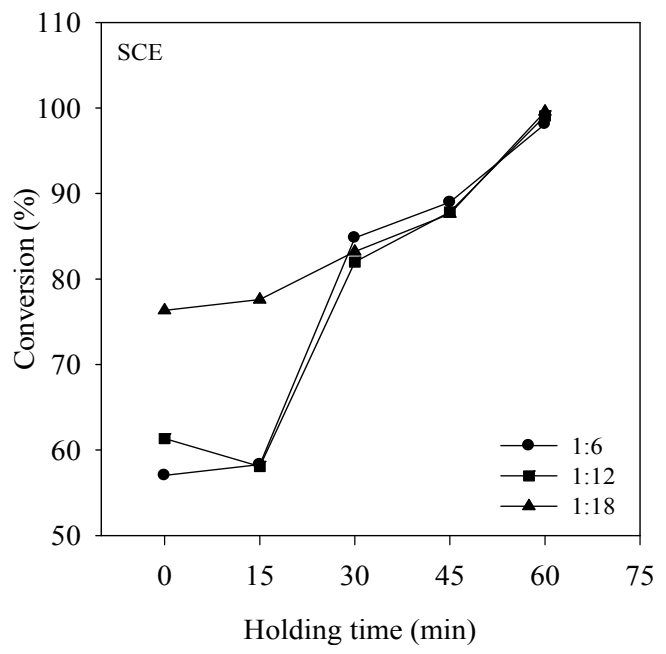

(a)

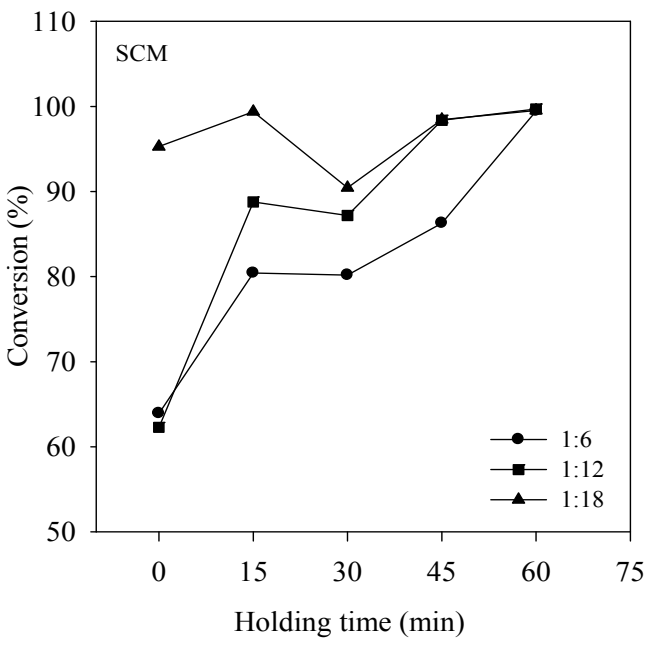

(b)

Figure 3. (a) SCE and (b) SCM based conversion at $290{ }^{\circ} \mathrm{C}$ for three different molar ratios of oil to alcohol at different retention time. 
The liquid product composition percent in terms of carbon number for SCM and SCE are demonstrated in Tables 2-5. In addition, the products have been classified as glycerol, non-esters and esters. From the tables, it can be inferred that $\mathrm{C} 17: 0, \mathrm{C} 18: 2, \mathrm{C} 18: 3$ and $\mathrm{C} 19: 1$ are the major components of transesterification of WVO using SCM while C18:0, C20:1, C20:2 and C20:3 are the major components while using SCE. This distinctly shows the effect of addition of one extra carbon from ethanol to the product. It is difficult to completely characterize the reaction products because of the numerous reaction paths and the variety of reaction products. The basic mechanism of transesterification of triglycerides with alcohol along with the mechanism of thermal decomposition of triglycerides is discussed by Schwab et al. [37]. Transesterification consists of a series of forward and reversible reactions. It can be inferred from the tables that the presence of glycerol is significant in using SCM while glycerol is almost absent while using SCE as solvent. The absence of glycerol in SCE results into slightly higher amount of products in the biodiesel range. The presence of glycerol in the solution helps to drive the equilibrium towards reactant, lowering the yield of esters [38]. Methanol and ethanol are not miscible with triglycerides at ambient temperature, and the reaction mixtures are usually mechanically stirred to enhance mass transfer. Emulsions usually form during this course of reaction. In the case of methanolysis, these emulsions quickly and easily break down forming a lower glycerol rich layer and upper methyl ester rich layer. In ethanolysis, these emulsions are more stable and severely complicate the separation and purification of esters [39]. The absence of glycerol in using SCE will strengthen its usability compared to SCM resulting into increased ester content. Tables 2 and 3 show the indifference of transesterification temperature $\left(250,270\right.$ and $\left.290^{\circ} \mathrm{C}\right)$ on the product composition. Although the conversion increased on increasing the transesterification temperature from 250 to $290^{\circ} \mathrm{C}$, no variation was seen on ester composition. The prominent series of forward and backward reaction during supercritical transesterification lead into the complex product combination. Furthermore, in Tables 4 and 5, it can be seen that no significant variation in ester composition occurred on varying WVO to alcohol ratio. Transesterification temperature of $250{ }^{\circ} \mathrm{C}$ and molar ratio of 1:6 is sufficient to obtain the maximum possible conversion. The fact that the critical temperatures of alcohols $\left(T_{\mathrm{C}}=239.45^{\circ} \mathrm{C}\right.$ and $240.75{ }^{\circ} \mathrm{C} ; P_{\mathrm{C}}=80.9$ and $61.4 \mathrm{bar} ; \rho_{\mathrm{c}}=0.272 \mathrm{~g} / \mathrm{cm}^{3}$ and $0.276 \mathrm{~g} / \mathrm{cm}^{3}$ for methanol and ethanol, respectively) are similar is due to the products obtained in terms of esters are similar, with a difference of one carbon. The similarity, with some exceptions, is due to the resemblance between the two alcohols in terms of chemical characteristics. The trend of the products obtained is similar to that of the results obtained for transesterification of waste pig fat in supercritical alcohols by Jeeban et al. [40]. The results obtained in Tables $2-5$ demonstrate that no significant variation was obtained on ester composition on increasing the transesterification temperature and retention time. However, from Figures 2 and 3, it can be concluded that the conversion increased with increase in transesterification temperature, retention time and molar ratio. Combining, these two results it can be concluded that transesterification temperature of $250{ }^{\circ} \mathrm{C}$, retention time of $0 \mathrm{~min}$ and molar ratio of 1:6 is enough to obtain maximum possible ester composition even though the conversion is much less than $100 \%$. Kusdaina and Saka [31] attained $95 \mathrm{wt} . \%$ conversion in methyl esters in about 240s of reaction in batch reactor while Minami and Saka [36] also reported conversions of around $90 \mathrm{wt} . \%$ in $30 \mathrm{~min}$ reaction for methyl esterification of oleic acid in continuous mode. The amount of glycerol and non-ester composition is much less, which results in higher amount of product in the biodiesel range. The presence of glycerol in solution helps drive the equilibrium towards reactant, lowering the yield of esters [39]. The non-ester component and glycerol collectively is less than 5\% for both SCM and SCE. 
Table 2. Product composition according to carbon number on varying transesterification temperature for SCM (supercritical methanol) at molar ratio of 1:6.

\begin{tabular}{|c|c|c|c|c|c|c|c|c|c|c|c|c|c|}
\hline \multicolumn{14}{|c|}{ Esters } \\
\hline & & & & & & $0 \mathrm{~min}$ & & & & & & & \\
\hline Temperature $\left({ }^{\circ} \mathrm{C}\right)$ & Glycerol & C10:2 & C12:0 & C15:0 & C17:0 & C17:1 & C18:2 & C18:3 & C19:0 & C19:1 & C21:1 & C28:0 & Non-esters \\
\hline 250 & - & 1.79 & 0.57 & - & 16.61 & - & 40.48 & 4.64 & - & 35.89 & - & - & 0.02 \\
\hline 270 & - & 0.64 & 0.45 & - & 16.09 & - & 42.15 & 4.68 & - & 35.80 & - & - & 0.19 \\
\hline 290 & - & - & 2.68 & 0.30 & 15.37 & 1.03 & 37.04 & 4.89 & - & 37.26 & - & - & 1.43 \\
\hline \multicolumn{14}{|c|}{$15 \mathrm{~min}$} \\
\hline 250 & - & - & 0.34 & 0.20 & 16.05 & - & 42.47 & 4.80 & - & 35.93 & - & - & 0.21 \\
\hline 270 & - & 0.13 & 0.26 & 0.20 & 16.59 & - & 40.36 & 4.93 & - & 36.39 & 1.14 & - & 1.14 \\
\hline 290 & - & 0.07 & 3.36 & 0.28 & 14.64 & 1.06 & 38.19 & 5.30 & - & 36.18 & - & - & 0.92 \\
\hline \multicolumn{14}{|c|}{$30 \mathrm{~min}$} \\
\hline 250 & - & 0.19 & 0.47 & 0.21 & 16.10 & - & 41.52 & 4.72 & - & 35.68 & - & - & 1.11 \\
\hline 270 & - & 0.11 & - & 0.20 & 16.52 & - & 39.57 & 5.42 & - & 36.57 & 1.27 & - & 1.61 \\
\hline 290 & 0.66 & 0.09 & 3.02 & 0.26 & 14.64 & 0.92 & 38.48 & 5.35 & - & 36.31 & - & 0.07 & 0.27 \\
\hline \multicolumn{14}{|c|}{$45 \mathrm{~min}$} \\
\hline 250 & - & 0.41 & 0.14 & 0.20 & 16.53 & - & 39.93 & 5.44 & - & 36.35 & 1.01 & - & 1.00 \\
\hline 270 & 0.22 & 0.11 & - & 0.21 & 16.58 & - & 38.69 & 5.41 & 0.32 & 36.69 & 1.54 & - & 1.77 \\
\hline 290 & 1.14 & - & 2.72 & 0.27 & 14.21 & 1.18 & 39.58 & 5.45 & - & 35.45 & - & - & \\
\hline \multicolumn{14}{|c|}{$60 \mathrm{~min}$} \\
\hline 250 & - & 0.29 & 0.23 & 0.21 & 16.79 & - & 39.75 & 5.07 & - & 36.74 & 0.91 & - & 0.92 \\
\hline 270 & 0.37 & 0.20 & - & 0.20 & 16.75 & - & 38.79 & 5.39 & - & 36.87 & 1.32 & - & 1.43 \\
\hline 290 & 1.27 & 0.08 & 1.19 & 0.27 & 13.97 & 1.08 & 39.84 & 5.34 & 0.81 & 35.76 & - & - & 0.39 \\
\hline
\end{tabular}


Table 3. Product composition according to carbon number on varying transesterification temperature for SCE at molar ratio of 1:6.

\begin{tabular}{|c|c|c|c|c|c|c|c|c|c|c|}
\hline \multicolumn{11}{|c|}{ Esters } \\
\hline & & & & & $\min$ & & & & & \\
\hline Temperature $\left({ }^{\circ} \mathrm{C}\right)$ & Glycerol & C10:2 & C12:0 & C16:0 & C18:0 & C20:0 & C20:1 & C20:2 & C20:3 & Non-esters \\
\hline 250 & - & 11.20 & 13.78 & - & 13.79 & - & 24.21 & 34.22 & & 2.80 \\
\hline 290 & - & - & 0.34 & - & 16.15 & - & 37.11 & 43.37 & 3.03 & - \\
\hline \multicolumn{11}{|c|}{$15 \min$} \\
\hline 250 & - & 0.54 & - & - & 15.15 & 3.36 & 32.07 & 43.75 & 5.13 & - \\
\hline 270 & - & - & 0.07 & - & 15.53 & 2.72 & 34.38 & 43.74 & 3.37 & 0.19 \\
\hline \multicolumn{11}{|c|}{$30 \mathrm{~min}$} \\
\hline 250 & - & 0.33 & - & - & 15.90 & 2.69 & 33.46 & 42.55 & 5.03 & 0.04 \\
\hline 270 & - & - & - & - & 16.45 & - & 37.22 & 42.89 & 3.30 & 0.14 \\
\hline 290 & - & - & 0.61 & 0.13 & 16.53 & - & 37.06 & 40.76 & 4.91 & - \\
\hline \multicolumn{11}{|c|}{$45 \mathrm{~min}$} \\
\hline 250 & - & 0.21 & 0.37 & - & 16.33 & - & 36.41 & 41.36 & 5.08 & 0.24 \\
\hline 270 & - & - & - & 0.18 & 16.16 & - & 37.07 & 40.54 & 5.24 & 0.81 \\
\hline 290 & 0.93 & - & 0.08 & 0.22 & 15.78 & - & 37.19 & 40.63 & 4.86 & 0.31 \\
\hline
\end{tabular}


Table 4. Product composition according to carbon number on varying molar ratio for SCM at transesterification temperature of $290{ }^{\circ} \mathrm{C}$.

\begin{tabular}{|c|c|c|c|c|c|c|c|c|c|c|c|c|c|c|}
\hline \multicolumn{15}{|c|}{ Esters } \\
\hline \multicolumn{15}{|c|}{$0 \min$} \\
\hline M.R & Glycerol & C10:2 & $\mathrm{C} 12: 0$ & C15:0 & C17:0 & C17:1 & C18:0 & C18:2 & C18:3 & C19:0 & C19:1 & C21:0 & C28:0 & Non-esters \\
\hline $1: 6$ & - & - & 2.68 & 0.30 & 15.37 & 1.03 & - & 37.04 & 4.89 & - & 37.26 & - & - & 1.43 \\
\hline $1: 12$ & - & 0.17 & 1.21 & 0.25 & 14.98 & 0.82 & - & 37.70 & 5.12 & - & 37.63 & - & 0.02 & 2.12 \\
\hline 1:18 & 2.64 & 0.55 & 1.12 & 0.28 & 14.93 & 0.97 & - & 36.16 & 4.82 & - & 37.05 & 0.98 & - & 1.48 \\
\hline \multicolumn{15}{|c|}{$15 \mathrm{~min}$} \\
\hline $1: 6$ & - & 0.07 & 3.36 & 0.28 & 14.64 & 1.06 & - & 38.19 & 5.30 & - & 36.18 & - & - & 0.92 \\
\hline $1: 12$ & 1.71 & 0.11 & 1.09 & 0.25 & 14.67 & 0.76 & - & 37.53 & 5.05 & 1.78 & 35.40 & - & - & 1.65 \\
\hline 1:18 & 2.60 & 0.15 & 0.99 & 0.26 & 14.45 & 0.92 & - & 37.33 & 5.26 & - & 36.20 & - & - & 1.84 \\
\hline \multicolumn{15}{|c|}{$30 \mathrm{~min}$} \\
\hline $1: 6$ & 0.66 & 0.09 & 3.02 & 0.26 & 14.64 & 0.92 & - & 38.48 & 5.35 & - & 36.31 & - & 0.07 & 0.27 \\
\hline $1: 12$ & 1.79 & 0.09 & 0.69 & 0.26 & 14.33 & 0.96 & - & 39.65 & 5.24 & - & 35.98 & - & - & 1.01 \\
\hline 1:18 & 2.56 & 0.08 & 0.70 & 0.26 & 14.09 & 0.85 & - & 37.49 & 5.39 & 1.84 & 35.83 & - & 0.13 & 0.91 \\
\hline \multicolumn{15}{|c|}{$45 \mathrm{~min}$} \\
\hline $1: 6$ & 1.14 & - & 2.72 & 0.27 & 14.21 & 1.18 & - & 39.58 & 5.45 & - & 35.45 & - & - & - \\
\hline $1: 12$ & 2.44 & 0.05 & 1.28 & 0.26 & 13.66 & 1.03 & 0.33 & 39.77 & 5.39 & - & 35.53 & - & 0.06 & 0.26 \\
\hline 1:18 & 2.58 & 0.08 & 0.22 & 0.26 & 14.07 & 0.79 & 0.21 & 37.71 & 5.40 & 2.30 & 35.94 & - & - & 0.44 \\
\hline \multicolumn{15}{|c|}{$60 \mathrm{~min}$} \\
\hline $1: 6$ & 1.27 & 0.08 & 1.19 & 0.27 & 13.97 & 1.08 & & 39.84 & 5.34 & 0.81 & 35.76 & - & - & 0.39 \\
\hline $1: 12$ & 2.44 & - & 0.60 & 0.27 & 13.95 & 0.98 & 0.23 & 39.60 & 5.07 & 0.79 & 35.69 & - & - & 0.38 \\
\hline $1: 18$ & 2.60 & 0.07 & 0.32 & 0.26 & 14.24 & 0.88 & 0.20 & 39.75 & 4.91 & 0.48 & 35.87 & - & - & 0.42 \\
\hline
\end{tabular}


Table 5. Product composition according to carbon number on varying molar ratio for SCE at transesterification temperature of $290{ }^{\circ} \mathrm{C}$.

\begin{tabular}{|c|c|c|c|c|c|c|c|c|c|c|c|}
\hline \multicolumn{12}{|c|}{ Esters } \\
\hline \multicolumn{12}{|c|}{$0 \min$} \\
\hline M.R & Glycerol & $\mathrm{C} 10: 2$ & $\mathrm{C} 12: 0$ & C16:0 & C17:0 & C18:0 & C19:1 & C20:1 & C20:2 & C20:3 & Non-esters \\
\hline $1: 6$ & - & - & 0.34 & - & - & 16.15 & - & 37.11 & 43.37 & 3.03 & 0.00 \\
\hline $1: 12$ & - & 0.45 & 0.04 & - & - & 16.50 & - & 37.63 & 42.10 & 2.96 & 0.32 \\
\hline $1: 18$ & - & 0.78 & - & - & - & 17.75 & - & 37.25 & 39.83 & 4.15 & 0.24 \\
\hline \multicolumn{12}{|c|}{$15 \mathrm{~min}$} \\
\hline $1: 6$ & - & - & - & - & - & 16.33 & - & 36.78 & 43.20 & 3.50 & 0.19 \\
\hline $1: 12$ & 1.44 & 0.18 & 0.08 & 0.23 & 0.30 & 15.75 & 0.72 & 37.38 & 38.86 & 4.67 & 0.39 \\
\hline 1:18 & - & - & - & 0.28 & - & 13.31 & - & 35.63 & 41.60 & 5.53 & 3.65 \\
\hline \multicolumn{12}{|c|}{$30 \mathrm{~min}$} \\
\hline $1: 6$ & - & - & 0.61 & 0.13 & - & 16.53 & - & 37.06 & 40.76 & 4.91 & 0.00 \\
\hline $1: 12$ & 2.00 & 0.11 & - & 0.24 & 1.70 & 13.90 & 4.15 & 36.54 & 35.77 & 4.38 & 1.21 \\
\hline $1: 18$ & 3.94 & - & - & 0.21 & - & 13.18 & - & 35.49 & 41.06 & 5.41 & 0.71 \\
\hline \multicolumn{12}{|c|}{$45 \mathrm{~min}$} \\
\hline $1: 6$ & - & - & - & 0.16 & - & 16.08 & - & 37.16 & 40.71 & 4.90 & 0.99 \\
\hline $1: 12$ & 2.15 & - & 0.32 & 0.25 & 0.13 & 14.65 & - & 36.33 & 39.64 & 5.13 & 1.40 \\
\hline 1:18 & 3.95 & - & - & 0.21 & - & 13.43 & - & 35.55 & 41.43 & 5.42 & 0.01 \\
\hline \multicolumn{12}{|c|}{$60 \mathrm{~min}$} \\
\hline $1: 6$ & 0.93 & - & 0.08 & 0.22 & - & 15.78 & - & 37.19 & 40.63 & 4.86 & 0.31 \\
\hline $1: 12$ & 4.21 & - & - & 0.23 & - & 13.58 & - & 35.66 & 39.74 & 5.73 & 0.85 \\
\hline $1: 18$ & 4.20 & - & 0.17 & 0.21 & - & 13.23 & - & 35.38 & 40.37 & 5.62 & 0.82 \\
\hline
\end{tabular}


The difference in the product obtained while using SCM and SCE is still ambiguous as shown by many researches [32,41,42]. Numerous studies [23,30] have shown the suitability of SCM in biodiesel production, while studies by Madras et al. [29] and Poudel and Oh [43] have presented the suitability of SCE over SCM. Thus, this field still needs deeper and concrete comparative studies. From an environmental point of view, the requirement of methanol makes the current biodiesel product not totally $100 \%$ renewable as methanol is derived from fossil-based products. Ethanol, on the other hand, can be produced from agricultural biomass via fermentation technology and is easily available in the market at high purity [44]. However, if ethanol is produced from cash or edible crops, it poses threat to the human civilization. Therefore, detail analysis considering the pros and cons of SCM and SCE is required before concluding the superiority of one or the other. However, the cost factor and availability plays crucial role for selecting either SCM or SCE.

\section{Conclusions}

The conversion of WVO increased with increase in transesterification temperature, retention time and oil to alcohol molar ratio. The conversion obtained for lower holding time is lower for SCE for all transesterification temperatures while the conversion for SCE abruptly increases for higher holding time. This is due to the hydrogen bonding in ethanol, which is comparatively higher than that of methanol in lower temperature and lower holding time, but reverses as temperature increases. As the increase in molar ratio intensifies the purification process, optimum molar ratio should be contemplated during application. Owing to the variation in carbon number in ethanol and methanol, $\mathrm{C} 17: 0, \mathrm{C} 18: 2, \mathrm{C} 18: 3$ and $\mathrm{C} 19: 1$ are the major components of transesterification of WVO when using SCM, whereas C18:0, C20:1. C20:2 and C20:3 are the major components when using SCE. The total amount of glycerol and non-ester composition is less than 5\% resulting into ester yield above 95\%. Due to ambiguity of the use of ethanol and methanol as solvents, cost factor and availability should be highly considered along with other factors such as conversion, complexity of purification and toxicity.

Acknowledgments: This work was supported by a Grant from Kongju National University, Korea and Human Resources Development Program (No. 20154030200940) of the Korea Institute of Energy Technology Evaluation and Planning (KETEP) funded by the Ministry of Trade, Industry and Energy of the Korean government.

Author Contributions: Sujeeta Karki, Nawaraj Sanjel, Jeeban Poudel and Ja Hyung Choi equally contributed to produce the experimental data, analyze the data and produce the final manuscript. Sujeeta Karki was responsible for final editing and proofreading. Sea Cheon Oh supervised the research and finalized the paper.

Conflicts of Interest: The authors declare no conflict of interest.

\section{References}

1. Munack, A.; Schröder, O.; Krahl, J.; Bünger, J. Comparison of relevant exhaust gas emissions from biodiesel and fossil diesel fuel. International Commission of Agricultural Engineering. Agric. Eng. 2001, 3, 1-8.

2. Saravanan, S.; Nagarajan, G.; Rao, G.L.N.; Sampath, S. Feasibility study of crude rice bran oil as a diesel substitute in a DI-CI engine without modifications. Energy Sustain. Dev. 2007, 11, 83-92. [CrossRef]

3. Owolabi, R.; Osiyemi, N.; Amosa, M.; Ojewumi, M. Biodiesel from household/restaurant waste cooking oil (WCO). J. Chem. Eng. Process. Technol. 2011, 2, 700.

4. Van Gerpen, J. Biodiesel processing and production. Fuel Process Technol. 2005, 86, 1097-1107. [CrossRef]

5. Srivastava, A.; Prasad, R. Triglycerides-based diesel fuels. Renew. Sustain. Energ. Rev. 2000, 4, 111-133. [CrossRef]

6. Demirbas, A. Progress and recent trends in biodiesel fuels. Energ. Convers. Manag. 2009, 50, 14-34. [CrossRef]

7. Alcantara, R.; Amores, J.; Canoira, L.T.; Fidalgo, E.; Franco, M.; Navarro, A. Catalytic production of biodiesel from soy-bean oil, used frying oil and tallow. Biomass Bioenergy 2000, 18, 515-527. [CrossRef]

8. Mendes, A. Production of Biodiesel from Corn Oil and Ethanol by Homogeneous Alkali Catalyzed Transesterification. Available online: http://www.diva--portal.org/smash/record.jsf?pid=diva2\% 3A414004\&dswid=-3878 (accessed on 12 June 2016). 
9. Khaligh, N.G.; Hamid, S.B.A.; Mihankhah, T. Eco-friendly Biodiesel Production from Waste Olive Oil by Transesterification using Nano-tube $\mathrm{TiO}_{2}$. In Proceedings of the International Conference of Social Science, Medicine and Nursing, Istanbul, Turkey, 5-6 June 2015.

10. Royon, D.; Daz, M.; Ellenrieder, G.; Locatelli, S. Enzymatic production of biodiesel from cotton seed oil using t-butanol as a solvent. Bioresour. Technol. 2007, 98, 648-653. [CrossRef] [PubMed]

11. Rashid, U.; Anwar, F. Production of biodiesel through optimized alkaline-catalyzed transesterification of rapeseed oil. Fuel 2008, 87, 265-273. [CrossRef]

12. Shu, Q.; Gao, J.; Nawaz, Z.; Liao, Y.; Wang, D.; Wang, J. Synthesis of biodiesel from waste vegetable oil with largee amounts of free fatty acids using a carbon-based solid acid catalyst. Appl. Energy 2010, 87, 2589-2596. [CrossRef]

13. Alexander, C.; Hurt, C. Biofuels and Their Impact on Food Prices. 2007. Available online: https://www. extension.purdue.edu/extmedia/id/id-346-w.pdf (accessed on 1 April 2014).

14. Phan, A.N.; Phan, T.M. Biodiesel production from waste cooking oils. Fuel 2008, 87, 3490-3496. [CrossRef]

15. Meng, X.; Chen, G.; Wang, Y. Biodiesel production from waste cooking oil via alkali catalyst and its engine test. Fuel Process. Technol. 2008, 89, 851-857. [CrossRef]

16. Chhetri, A.B.; Watts, K.C.; Islam, M.R. Waste cooking oil as an alternate feedstock for biodiesel production. Energies 2008, 1, 3-18. [CrossRef]

17. Da Silva, N.D.L.; Rivera, E.C.; Batistella, C.B.; Maciel Filho, R.; Maciel, M.R.W. Biodiesel production from vegetable oils: Operational strategies for large scale systems. Comput. Aided Chem. Eng. 2008, 25, 1101-1106.

18. Ngamprasertsith, S.; Sawangkeaw, R. Transesterification in supercritical conditions. In Biodiesel-Feedstocks and Processing Technologies; InTechOpen: Rijeka, Croatia, 2011; pp. 247-268.

19. Meher, L.; Sagar, D.V.; Naik, S. Technical aspects of biodiesel production by transesterification-A review. Renew. Sustain. Energ. Rev. 2006, 10, 248-268. [CrossRef]

20. Felizardo, P.; Correia, M.J.N.; Raposo, I.; Mendes, J.F.; Berkemeier, R.; Bordado, J.M. Production of biodiesel from waste frying oils. Waste Manag. 2006, 26, 487-494. [CrossRef] [PubMed]

21. Chouhan, A.S.; Sarma, A. Modern heterogeneous catalysts for biodiesel production: A comprehensive review. Renew. Sustain. Energy Rev. 2011, 15, 4378-4399. [CrossRef]

22. Di Serio, M.; Tesser, R.; Pengmei, L.; Santacesaria, E. Heterogeneous catalysts for biodiesel production. Energy Fuels 2007, 22, 207-217. [CrossRef]

23. Warabi, Y.; Kusdiana, D.; Saka, S. Reactivity of triglycerides and fatty acids of rapeseed oil in supercritical alcohols. Bioresour. Technol. 2004, 91, 283-287. [CrossRef]

24. Köckritz, A.; Martin, A. Oxidation of unsaturated fatty acid derivatives and vegetable oils. Eur. J. Lipid Sci. Technol. 2008, 110, 812-824. [CrossRef]

25. Demirbaş, A. Biodiesel from vegetable oils via transesterification in supercritical methanol. Energy Convers. Manag. 2002, 43, 2349-2356. [CrossRef]

26. Martini, N.; Schell, J.S. Plant oils as fuels: Present state of science and future developments. J. Taiwan Inst. Chem. Eng. 2016. [CrossRef]

27. Demirbas, A. Biodiesel from waste cooking oil via base-catalytic and supercritical methanol transesterification. Energy Convers. Manag. 2009, 50, 923-927. [CrossRef]

28. Lam, M.K.; Lee, K.T.; Mohamed, A.R. Homogeneous, heterogeneous and enzymatic catalysis for transesterification of high free fatty acid oil (waste cooking oil) to biodiesel: A review. Biotechnol. Adv. 2010, 28, 500-518. [CrossRef] [PubMed]

29. Zhang, Y.; Dube, M.; McLean, D.; Kates, M. Biodiesel production from waste cooking oil: 1. Process design and technological assessment. Bioresour. Technol. 2003, 89, 1-16. [CrossRef]

30. Sanjel, N.; Gu, J.H.; Oh, S.C. Transesterification Kinetics of Waste Vegetable Oil in Supercritical Alcohols. Energies 2014, 7, 2095-2106. [CrossRef]

31. Saka, S.; Kusdiana, D. Biodiesel fuel from rapeseed oil as prepared in supercritical methanol. Fuel 2001, 80, 225-231. [CrossRef]

32. Hoffmann, M.M.; Conradi, M.S. Are there hydrogen bonds in supercritical methanol and ethanol? J. Phys. Chem. B 1998, 102, 263-271. [CrossRef]

33. Madras, G.; Kolluru, C.; Kumar, R. Synthesis of biodiesel in supercritical fluids. Fuel 2004, 83, $2029-2033$. [CrossRef] 
34. Tan, K.T.; Gui, M.M.; Lee, K.T.; Mohamed, A.R. An optimized study of methanol and ethanol in supercritical alcohol technology for biodiesel production. J. Supercrit. Fluids 2010, 53, 82-87. [CrossRef]

35. Tan, K.T.; Gui, M.M.; Lee, K.T.; Mohamed, A.R. Supercritical alcohol technology in biodiesel production: A comparative study between methanol and ethanol. Energy Sour. Part A. 2010, 33, 156-163. [CrossRef]

36. Minami, E.; Saka, S. Kinetics of hydrolysis and methyl esterification for biodiesel production in two-step supercritical methanol process. Fuel 2006, 85, 2479-2483. [CrossRef]

37. Schwab, A.W.; Dykstra, G.J.; Selke, E.; Sorenson, S.C.; Pryde, E.H. Diesel Fuel from Thermal Decomposition of Soybean Oil. JAOCS 1988, 65, 1781-1786. [CrossRef]

38. Tomasevic, A.; Siler-Marinkovic, S. Methanolysis of used frying oil. Fuel Process. Technol. 2003, 81, 1-6. [CrossRef]

39. Zhou, W.; Konar, S.K.; Boocock, D.G. Ethyl esters from the single-phase base-catalyzed ethanolysis of vegetable oils. J. Am. Oil Chem. Soc. 2003, 80, 367-371. [CrossRef]

40. Poudel, J.; Shah, M.; Karki, S.; Oh, S.C. Qualitative Analysis of Transesterification of Waste Pig Fat in Supercritical Alcohols. Energies 2017, 10, 265. [CrossRef]

41. Barlow, S.J.; Bondarenko, G.V.; Gorbaty, Y.E.; Yamaguchi, T.; Poliakoff, M. An IR study of hydrogen bonding in liquid and supercritical alcohols. J. Phys. Chem. A 2002, 106, 10452-10460. [CrossRef]

42. Zhang, Y.; Yang, J.; Yu, Y.; Li, Y. Structural and hydrogen bond analysis for supercritical ethanol: A molecular simulation study. J. Supercrit. Fluids 2005, 36, 145-153. [CrossRef]

43. Poudel, J.; Oh, S.C. A kinetic analysis of wood degradation in supercritical alcohols. Ind. Eng. Chem. Res. 2012, 51, 4509-4514. [CrossRef]

44. Gui, M.M.; Lee, K.T.; Bhatia, S. Supercritical ethanol technology for the production of biodiesel: Process optimization studies. J. Supercrit. Fluids 2009, 49, 286-292. [CrossRef]

(C) 2017 by the authors. Licensee MDPI, Basel, Switzerland. This article is an open access article distributed under the terms and conditions of the Creative Commons Attribution (CC BY) license (http:/ / creativecommons.org/licenses/by/4.0/). 